\title{
Voting on Labour-Market Integration and Education Policy when Citizens Differ in Mobility and Ability
}

\author{
ALEXANDER HAUPT \\ SILKE UEBELMESSER
}

CESIFo Working PAPER No. 2588

CATEgory 2: Public Choice

MARCH 2009

\footnotetext{
An electronic version of the paper may be downloaded

- from the SSRN website:

- from the RePEc website:

www.SSRN.com

Www.RePEc.org

- from the CESifo website:

www.CESifo-group.org/wp
} 


\title{
Voting on Labour-Market Integration and Education Policy when Citizens Differ in Mobility and Ability
}

\begin{abstract}
We analyse how institutional and political decisions are intertwined. Citizens who differ in their mobility and ability vote first on labour market integration and afterwards on education policy. The institutional decision on integration influences the succeeding education policy. More surprisingly, the prospect of voting on education policy also affects the preceding integration decision. There are incentives for citizens to vote strategically for the institutional setting in which their preferred education policy is more successful at the polls. We show how a 'joint' analysis of the institutional and political decision alters the results compared to an 'isolated' analysis of either of the two decisions. Also, we explore how the two-dimensional heterogeneity of the citizens shapes the voting equilibrium in our setting with sequential voting.
\end{abstract}

JEL Code: D72, F22, H52, I28.

Keywords: voting, labour-market integration, education policy, migration.

\author{
Alexander Haupt \\ Plymouth Business School \\ University of Plymouth \\ Drake Circus \\ UK - Plymouth, PL4 8AA \\ alexander.haupt@plymouth.ac.uk
}

\author{
Silke Uebelmesser \\ Center for Economic Studies at the \\ University of Munich \\ Schackstrasse 4 \\ Germany - 80539 Munich \\ uebelmesser@lmu.de
}

January 2009

We are indebted to Stan Winer and two referees for insightful comments and very helpful advice. We have also benefited from discussions at a workshop of the German Research Foundation (DFG) in Dresden, at the annual meeting of the German Economic Association in Graz, and at a seminar at the Social Science Research Center Berlin (WZB). A. Haupt gratefully acknowledges financial support from the German Research Foundation (DFG) within the Priority Programme SPP 1142. 


\section{MOTIVATION}

Political decisions take place within a particular institutional framework. This institutional framework affects the benefits of different political alternatives and the distribution of these benefits across the electorate. It thus influences the support for different alternatives at the polls. Once citizens are aware of this forward linkage between the institutional framework and the succeeding political decisions, this relationship will in turn affect their preferences over different institutional settings. The choice of the institutional framework itself is then influenced by its impact on the succeeding political decisions. Each voter faces an incentive to strategically support an institutional arrangement that later raises the number of votes for the preferred policy. Thus, there is also a backward linkage, meaning that future political decisions affect preceding institutional ones.

In this paper, we analyse these interactions between the institutional and the political decisions. More precisely, we explore the interplay between the institutional decision on labourmarket integration and the political decision concerning the quality of public education. We focus on the choices in a poor, small country whose labour market can be integrated into the labour market of a rich, large jurisdiction. The citizens of the small country are characterised by different ability and mobility levels. This two-dimensional heterogeneity gives rise to individually distinct preferences over integration regimes and education policies.

Public decision making is captured here by a model with sequential voting. The citizens of the small country first vote on the integration regime and then on the education policy. As we will argue, this timing reflects a 'natural hierarchy' of rather long-run institutional and short-run political decisions. Each of the two elections is boiled down to a zero-one decision, and in each stage the alternative that gains the majority of votes is implemented.

This very simple structure enables us to highlight how a joint analysis of the institutional and political decision alters the results compared to an isolated analysis of either of the two decisions. For instance, in the case of an exogenously given education policy, a citizen's preferred integration regime - non-integrated or integrated labour markets - depends on her mobility only. However, once the decision on education policy is also endogenously determined, each voter's favoured integration regime depends on both her mobility and ability. So, the two-dimensional 
heterogeneity of the citizens becomes important when the interplay between the institutional and the political decision is taken into account.

More importantly, the interaction between these decisions might reverse the election outcome compared to isolated votes. Under some circumstances, labour-market integration does not gain a majority at the polls for any exogenously given education policy. Yet under the very same circumstances integration wins if the education policy is also endogenously determined. The reason is that some citizens now strategically vote for labour-market integration, since their favoured education policy gains a majority only with this institutional arrangement. Again, the interaction between the two decisions makes all the difference.

Our paper is mainly related to three strands of the literature. First, a number of articles analyse the potentially positive effects of open borders on human capital formation. For instance, Stark, Helmenstein and Prskawetz (1998), Stark and Wang (2002) and Vidal (1998) all argue that the opportunity of emigration raises private investment in education. ${ }^{1}$ Unlike these articles, we consider the incentives of integrated labour markets on investment in public education. These incentives are very different as a consequence of the very different distributional implications of public and private investments. In our model, labour-market integration can lead to more or less public spending on education. Wildasin (2000) also analyses publicly financed education in the context of labour-market integration, but, like the other papers mentioned above, voting is not considered at all and integration is exogenously given.

Second, there is a well-developed literature on the political economy of education. For instance, De Fraja (2001), Epple and Romano (1996), Fernandez and Rogerson (1995) and Stiglitz (1974) analyse voting on education policy and the redistributional implications of the election outcome. Unlike our paper, however, none of these papers links this political choice with voting on a second issue. Similarly, several papers which analyse education policy in a dynamic setting focus entirely on one-dimensional voting (see, e.g., Glomm and Ravikumar, 1992, Gradstein and Justman, 1997, Haupt, 2005, and Soares, 2003).

Few papers extend this literature by considering two-dimensional voting on education policy and social security as two parts of an intergenerational contract (see, e.g., Rangel, 2003). There, the analysis is, however, restricted to individuals who only differ in age. Poutvaara

\footnotetext{
${ }^{1}$ For an empirical analysis, see Beine, Docquier and Rapoport (2008).
} 
(2006) generalizes this approach by allowing for simultaneous voting on the wage tax rate and investment in public education when individuals differ in age and productivity and when the wage tax finances public education and pension benefits. He thus considers the linkages between different public expenditures and the consequences for the voting equilibria while we focus on incentives for strategic voting in the absence of any link via the public budget.

Third, our paper is also related to the political-economic literature on integration. In these contributions, citizens vote on political integration on grounds of public good provision (e.g., Alesina and Spolaore, 1997) or income distribution across regions (e.g., Bolton and Roland, 1997). Basically, these articles focus on the voters' trade-off between the efficiency gains of a large state and the benefits of having a government closer to their preferences in a small state (see Alesina and Spolaore, 2003, for an overview). By contrast, we are interested in the exact interaction between different public decisions within a given political entity.

The paper proceeds as follows: In the next section, we introduce our political-economic model. In Section 3, the equilibrium education policy is analysed for a given integration regime, and in Section 4, the emerging integration regime itself is explored. In Section 5, we discuss the additional insights that arise from considering two-dimensional voting instead of isolated votes. In particular, we focus on the interdependence of the two public decisions and the relevance of the two-dimensional heterogeneity. Section 6 concludes with some final remarks.

\section{THE POLITICAL-ECONOMIC MODEL}

In this section, we develop a simple political-economic model that allows us to analyse the interplay between voting on labour-market integration and education policy when citizens differ in ability and mobility. Our world consists of two entities - one rich, large jurisdiction and one poor, small jurisdiction. The focus here is on the political choices in the small jurisdiction and on migration from the small to the large jurisdiction. We first present the political framework before elaborating more on the economic setting.

\subsection{POLITICAL FRAMEWORK}

In the small jurisdiction, citizens have to take an institutional and a political decision. First, they vote on whether their country's labour market will be integrated into the larger juris- 
diction's one or not. This is a zero-one choice. In the case of integrated labour markets $(I)$, all legal and political barriers to the free movement of workers between the two jurisdictions are dismantled. By contrast, in the case of non-integrated labour markets $(N I)$, no interjurisdictional labour movement is possible. The large jurisdiction simply accepts the choice of the small country.

Second, the citizens of the small country vote on education policy $(E, t)$, where $E$ and $t$ stand for the quality of public education and the individual tax payment that is necessary to finance this policy. There are again two alternatives. Citizens choose either a low quality of public education $\underline{E}$ or a high quality $\bar{E}$, with $\bar{E}>\underline{E}$. While the low level $\underline{E}$ can be achieved at zero costs and zero taxes, the high level $\bar{E}$ leads to positive costs and thus requires positive taxes. In the latter case, a lump-sum tax $\bar{t}>0$ is levied on all citizens to finance public education spending. Note that all citizens, independent of their ultimate place of residence, pay this tax. ${ }^{2}$ Also, there is only public education; individuals do not have any private alternatives.

\subsection{ECONOMIC FRAMEWORK}

Individuals native to the small jurisdiction are ex-ante heterogeneous in two dimensions. First, they differ in their individual ability level $a$. This ability determines how effectively an individual can take advantage of the public education quality, as explored in more detail below.

Second, citizens differ in their inter-jurisdictional mobility. As will become evident soon, moving to the larger jurisdiction is always beneficial for the small country's citizens from a narrow economic point of view. However, even in the case of labour-market integration citizens migrate only with an individually specific probability $p$. Differences in this probability reflect the individual degree of attachment to one's native region. Some people have close links to their home region or find it difficult to cope with a new environment. Others, by contrast, have only weak ties to their native region or integrate into a new community easily. But even if people are mobile, migration is nothing that occurs with certainty. It is influenced by the environment of the individuals, in particular by their professional options and their social relations - be it

\footnotetext{
${ }^{2}$ The fiscal implication of migration, i.e. the loss of the tax base, is not considered here. Adding such fiscal effects, however, would only reinforce the downside of labour-market integration that is taken into account in our model. It would obviously weaken the case for integration, but without changing our qualitative results. For papers in which mobility of individuals also implies mobility of tax-payers, see, e.g., Andersson and Konrad (2003), Haupt and Janeba (2008), Poutvaara (2008), and Thum and Uebelmesser (2003). In a political-economic setting, Boerner and Uebelmesser (2007) not only study the effect of mobile tax-payers but also of mobile voters.
} 
preferences of an individual's partner, or parents and other relatives in need of care. Thus individual mobility is expressed in terms of an individual migration probability.

To capture the heterogeneity in both ability and mobility, the individual characteristics are assumed to be distributed according to a joint c.d.f $F(a, p):[0, \bar{a}] \times[0,1] \mapsto[0,1], \bar{a}>0$. Denoting the joint density by $f(a, p), \int_{0}^{1} \int_{0}^{\bar{a}} f(a, p) d a d p=1$ has to hold. For simplicity, the size of the population $N$ is normalised to one so that the joint density $f(a, p)$ is identical to the 'number' of individuals characterised by $(a, p)$. The distribution of these characteristics is common knowledge while the precise characteristics of an individual are only known to the individual herself. We do not impose any further assumption on the joint c.d.f $F(a, p)$. In particular, we neither presume nor exclude that ability and mobility are correlated. People who are identical in one dimension may well differ in the other. To emphasise this feature, we use different indices to indicate an individual's ability and mobility and refer to individuals as $\left(a_{i}, p_{j}\right)$-types in the following.

After having received education, each individual inelastically supplies one unit of labour, either at home or abroad. Wage $w_{i}$ of an individual with ability $a_{i}$ then depends on whether she stays in her country or, in the case of labour-market integration, emigrates to the other jurisdiction:

$$
w_{i}= \begin{cases}A(M) a_{i} E & \text { if the worker stays at home } \\ \delta a_{i} E & \text { if the worker emigrates. }\end{cases}
$$

For obvious reasons, the individual wage increases with the quality of public education $E$ and the individual ability $a_{i}$. Public education is the more effective, the better the individual ability, and vice versa. $A(M)$ and $\delta$ stand for the overall productivity of the economy at home and abroad, respectively, where $M, M \in[0,1]$, denotes the number or share of citizens of the small country leaving for the large jurisdiction. The function $A(M)$ decreases with migration $M$, capturing the negative impact of outmigration and the resultant loss of human capital for the source country. ${ }^{3}$

Productivities $A(M)$ and $\delta$ can be interpreted as wages per efficiency unit of educationaugmented ability at home and abroad, respectively. We assume that $\delta>A(M)$ holds for all

\footnotetext{
${ }^{3}$ With $A(M)$, we indirectly capture the aggregate level of human capital in the small economy, which declines as a result of outmigration. The positive impact of aggregate human capital on productivity has been discussed in great detail in the new economic growth literature. See, for instance, Barro and Sala-i-Martin (2003) for an overview.
} 
$M$ : the overall productivity is always higher in the rich jurisdiction than in the poor one. Thus, for all education and ability levels, the workers who are native to the small country receive higher wages abroad than at home. These wage differentials set the stage for migration from the small to the large jurisdiction when labour markets are integrated. By contrast, there are no incentives to move to the small country. Finally note that since the rich jurisdiction is large, any inflow from the small country is negligible and does not affect its productivity $\delta .{ }^{4}$

Individuals are risk-neutral and aim at maximising their (expected) net incomes. Having discussed individual wages, we can determine the expected net incomes of the small country's citizens. In the case of integrated labour markets $(I)$, migration is possible and beneficial. An individual of $\left(a_{i}, p_{j}\right)$-type emigrates and receives the wage $\delta a_{i} E$ with probability $p_{j}$; she stays at home and receives the wage $A(M) a_{i} E$ with probability $1-p_{j}$. No matter whether she moves or not, she has to pay the tax $t$. The expected net income of the $\left(a_{i}, p_{j}\right)$-type is thus given by

$$
B_{i j}^{I}=\left(1-p_{j}\right) A(M) a_{i} E+p_{j} \delta a_{i} E-t
$$

where $t=0(t=\bar{t})$ if $E=\underline{E}(E=\bar{E})$, as discussed above. Note that $M$ denotes here and in the following the expected number of emigrants.

In the case of non-integrated labour markets $(N I)$, emigration is no option and net income boils down to

$$
B_{i j}^{N I}=A(0) a_{i} E-t
$$

\subsection{TIMING AND INFORMATION}

Labour-market integration constitutes an institutional decision that is very difficult to change, at least in the short run; and any revision of such a decision takes time. By contrast, education policy can be altered much more easily, even in the short run. For this reason, we distinguish between long-run institutional and (potentially) short-run political decisions. To capture this decision hierarchy, voting is assumed to be sequential. At the first stage, the citizens of the small jurisdiction vote on labour-market integration. At the second stage, given the institutional choice, they vote on the quality of public education.

\footnotetext{
${ }^{4}$ Similar to $A(M), \delta$ can be seen as reflecting the level of human capital in the large region. Due to our 'small-and-poor-country' assumption, this level is, however, unaffected by migration in the course of labour market integration. The parameter $\delta$ can also capture the quality of education in the large country, which is again independent of the decisions in the small country. Thus, $\delta$ is constant.
} 
When the sequential voting takes place, each citizen knows her own ability level and migration probability as well as the distribution of individual characteristics. But she does not know whether she will ultimately migrate or not in the case of integrated labour markets. This will be revealed only after voting has taken place. A citizen's choice at the polls thus depends on her migration probability. Moreover, voters are rational and anticipate the impact of the decisions on their (expected) net income.

After the collective decisions have been made at the polls, the proposals that receive the majority of votes will be implemented, and all economic 'actions' will be carried out. Individuals will instantaneously acquire education given the quality of public education and their individual ability level, migrate with their individual probability in the case of integrated labour markets, supply inelastically one unit of labour, receive their wages and pay the resultant 'education' tax to their native jurisdiction. Since all economic actions occur 'automatically' in our politicaleconomic framework, this model allows us to focus entirely on the institutional and political choices and their interplay. We solve the model as usual by means of backward induction.

\section{VOTING ON EDUCATION POLICY}

We start by analysing the vote on education policy at the second stage. The individually preferred proposal, $(\underline{E}, 0)$ or $(\bar{E}, \bar{t})$, depends not only on the citizen's ability and mobility, but also on the outcome of the voting on labour-market integration at the first stage. The integration regime, either $(N I)$ or $(I)$, substantially affects the voter's incentives at the second stage. We analyse the vote on education policy first for non-integrated labour markets and then for integrated ones, thereby exploring the differences in the two cases in detail.

\subsection{NON-INTEGRATED LABOUR MARKETS}

In the case of non-integrated labour markets, institutional restrictions prevent any interjurisdictional migration. As individual mobility is irrelevant in this setting, the citizens de facto differ only in ability, and this characteristic determines their political preferences.

Each citizen supports the education policy that gives her the highest net income. Comparing individual net incomes $(3)$ for the alternatives $(\bar{E}, \bar{t})$ and $(\underline{E}, 0)$ yields

$$
\left.B_{i j}^{N I}\right|_{(\bar{E}, \bar{t})}=A(0) a_{i} \bar{E}-\bar{t} \gtreqless A(0) a_{i} \underline{E}=\left.B_{i j}^{N I}\right|_{(\underline{E}, 0)} \Longleftrightarrow a_{i} \gtreqless \frac{\bar{t}}{A(0)(\bar{E}-\underline{E})}=: a^{N I} .
$$


That is, all citizens with a high ability level $a_{i}$, i.e. $a_{i} \geq a^{N I}$, favour the education policy $(\bar{E}, \bar{t})$ while those with a low ability level $a_{i}$, i.e. $a_{i}<a^{N I}$, vote for the alternative $(\underline{E}, 0)$. The explanation for this result is straightforward. The individual wage rise in response to a higher quality of education is the larger, the higher the individual ability level. High-ability types particularly benefit from quality level $\bar{E}$ while the corresponding costs are equally shared among all citizens. Ultimately, education policy $(\bar{E}, \bar{t})$ redistributes from low-ability to highability types. ${ }^{5}$

The share of votes in favour of proposal $(\bar{E}, \bar{t})$ amounts to $V^{N I}=1-F\left(a^{N I}, 1\right)$, where $F\left(a^{N I}, 1\right)=\int_{0}^{1} \int_{0}^{a^{N I}} f(a, p) d a d p \cdot{ }^{6}$ Below, we will compare this share, which might or might not exceed 0.5 , with the corresponding share in the case of integrated labour markets.

\subsection{INTEGRATED LABOUR MARKETS}

We next consider voting in the case of integrated labour markets. Migration is now not only possible but also beneficial for all workers native to the small country, since the wage per efficiency unit is always higher abroad. So, some of the small country's citizens will move to the other jurisdiction.

Even if the identities of the future migrants are not known when individuals vote on education policies, the (expected) number of migrants will be correctly anticipated. It is given by $M=\int_{0}^{1} \int_{0}^{\bar{a}} p f(a, p) d a d p$. Individuals foresee the number of migrants as the distribution of characteristics, which completely determines $M$, is assumed to be common knowledge.

Each citizen votes again for the education policy that gives her the highest expected net income. Now, individual mobility in addition to individual ability shapes the political prefer-

\footnotetext{
${ }^{5}$ A similar redistribution occurs in Fernandez and Rogerson (1995), but for different reasons. In their paper, a majority deliberately pushes through an education policy that excludes the poor from higher education (see also Haupt, 2005). In our model, the redistribution results from our assumptions on the wage function (cf. (1)) and the tax system. If we replace the lump-sum tax by a progressive one, or if public education mainly increases the productivity of less able individuals, low-ability citizens might be the chief beneficiaries of public education. But even then, the fundamental mechanisms that we explore here and in the following would remain the same. All we need are two groups of individuals who benefit differently from public education and thus - as we will elaborate below - face different incentives to (strategically) vote on integration at the first stage. In any case, a coalition of low-ability and high-ability individuals against intermediate-ability individuals, i.e. a coalition of "the ends against the middle" (cf. Epple and Romano, 1996), cannot be an issue here as there is no possibility to opt out of the public system and receive privately provided education instead.

${ }^{6}$ More precisely, the upper limit of integration as to the ability level is $\widehat{a}=\min \left(a^{N I}, \bar{a}\right)$. For convenience, our notation abstracts from the possibility of a boundary solution.
} 
ences, as comparing expected net incomes for the education policies $(\bar{E}, \bar{t})$ and $(\underline{E}, 0)$ shows

$$
\begin{gathered}
\left.B_{i j}^{I}\right|_{(\bar{E}, \bar{t})}=\left(1-p_{j}\right) A(M) a_{i} \bar{E}+p_{j} \delta a_{i} \bar{E}-\bar{t} \gtreqless\left(1-p_{j}\right) A(M) a_{i} \underline{E}+p_{j} \delta a_{i} \underline{E}=\left.B_{i j}^{I}\right|_{(\underline{E}, 0)} \\
\Longleftrightarrow a_{i} \gtreqless \frac{\bar{t}}{\left[\left(1-p_{j}\right) A(M)+p_{j} \delta\right](\bar{E}-\underline{E})}=: a^{I}\left(p_{j}\right),
\end{gathered}
$$

where we make use of (2). Similarly to our previous result (see (4)), all citizens with a high ability level $a_{i}$, i.e. $a_{i} \geq a^{I}\left(p_{j}\right)$, favour the education policy $(\bar{E}, \bar{t})$ while those with a low ability level $a_{i}$, i.e. $a_{i}<a^{I}\left(p_{j}\right)$, vote for the alternative $(\underline{E}, 0)$. But in contrast to the outcome in the case of non-integrated markets, the critical ability level $a^{I}\left(p_{j}\right)$ is now individual-specific. It decreases with the individual migration probability $p_{j}$, which follows from our assumption about the productivity gap between the two countries, i.e. $\delta>A(M)$ for all $M$. Using the critical value $a^{I}\left(p_{j}\right)$, the share of votes in favour of policy $(\bar{E}, \bar{t})$ is given by $V^{I}=1-F\left(a^{I}\left(p_{j}\right), 1\right)$, where $F\left(a^{I}\left(p_{j}\right), 1\right)=\int_{0}^{1} \int_{0}^{a^{I}\left(p_{j}\right)} f(a, p) d a d p$.

\subsection{THE IMPACT OF INTEGRATION ON EDUCATION POLICY}

To identify the differences between the cases of integrated and non-integrated labour markets more clearly, we compare the critical ability levels (4) and (5), and find

$$
a^{I}\left(p_{j}\right) \gtreqless a^{N I} \Longleftrightarrow p_{j} \lesseqgtr \frac{A(0)-A(M)}{\delta-A(M)}=: p^{c} \in[0,1) .
$$

Figure 1 illustrates this relationship. It shows how labour-market integration changes the election outcome compared to the setting without integration. On the one hand, low-ability individuals, who vote for policy $(\underline{E}, 0)$ in a closed economy, support the proposal $(\bar{E}, \bar{t})$ in an open economy if they are sufficiently mobile. The characteristics $\left(a_{i}, p_{j}\right)$ of these 'floating' voters lie in area $\mathrm{C}$. On the other hand, high-ability individuals, who favour policy $(\bar{E}, \bar{t})$ in a closed economy, vote for proposal $(\underline{E}, 0)$ in an open economy if they are sufficiently immobile. Their characteristics $\left(a_{i}, p_{j}\right)$ lie in area B. For short, we refer to these two types as area-C types and area-B types, respectively. In contrast to these voters, area-A types support the proposal $(\bar{E}, \bar{t})$ independently of the integration regime while area-D types always favour policy $(\underline{E}, 0)$.

The economic explanation for the changes in the voting behaviour is straightforward. Education is the more effective, the more advanced an economy is in terms of productivity. Labour-market integration thus reinforces the positive impact of the quality of education on 
the wages of those workers who end up in the more productive jurisdiction. By contrast, it diminishes this positive impact on the wages of those individuals who remain in the small country, since outmigration distorts the domestic economy, reduces aggregate human capital and thus decreases its productivity. Hence, mobile workers now fancy education more even if they are less able while immobile workers become more reluctant to support a high education quality even if they are more able.

Figure 1: Voting on education policy

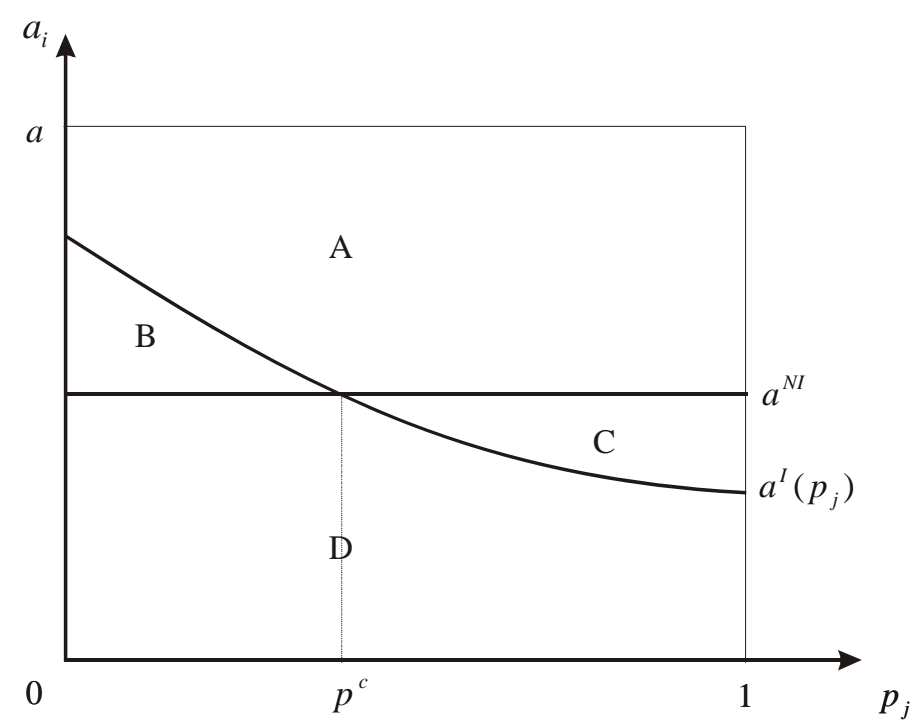

As a consequence of these opposing effects, the share of the vote in favour of proposal $(\bar{E}, \bar{t})$ can be greater or smaller in the case of integrated labour markets than in the case of non-integrated ones. If area-C types outnumber area-B types, the policy $(\bar{E}, \bar{t})$ will receive more votes in an open economy than in a closed one, i.e. $V^{I}>V^{N I}$. Otherwise, this policy will gain fewer votes with integrated labour-markets than without, i.e. $V^{I}<V^{N I}$.

The citizens' voting behaviour gives rise to two different cases. First, a dominant education policy can emerge, meaning that the type of integration regime in place, either $(I)$ or $(N I)$, has no effect on which proposal, either $(\bar{E}, \bar{t})$ or $(\underline{E}, 0)$, wins the election at the second stage. If $V^{I} \geq 0.5$ and $V^{N I} \geq 0.5$ result, the proposal $(\bar{E}, \bar{t})$ will gain a majority at the polls, no matter whether labour markets are integrated or not. ${ }^{7}$ Similarly, the alternative $(\underline{E}, 0)$ will always win

\footnotetext{
${ }^{7}$ For convenience, the policy $(\bar{E}, \bar{t})$ is assumed to win the election if $V=0.5$ holds. This does not affect our qualitative results.
} 
in the election if $V^{I}<0.5$ and $V^{N I}<0.5$ hold.

Second, an integration-driven education policy might arise, meaning that the type of integration regime in place ultimately predetermines which proposal wins in the election at the second stage. If $V^{I} \geq 0.5>V^{N I}$ holds, the proposal $(\bar{E}, \bar{t})$ wins in the election in an open economy while the policy $(\underline{E}, 0)$ receives a majority in a closed economy. By contrast, if $V^{N I} \geq 0.5>V^{I}$ results, the proposal $(\bar{E}, \bar{t})$ receives a majority only in a closed economy while the alternative $(\underline{E}, 0)$ is successful at the polls in an open economy. ${ }^{8}$

The distinction between dominant and integration-driven education policies proves to be important for analysing the election outcome at the first stage. We explore the details in the next section.

\section{VOTING ON LABOUR-MARKET INTEGRATION}

As we have shown, the outcome of the vote on education policy can hinge on the integration regime. This potential impact of the integration regime on the chosen education policy affects the decision on labour-market integration itself, as we will see in this section. To analyse the outcome of the election at the first stage, we take up our previous categorisation. We first consider cases in which a dominant education policy emerges. Then, we look at cases in which an integration-driven education policy arises.

\subsection{DOMINANT EDUCATION POLICY}

If $V^{I} \geq 0.5$ and $V^{N I} \geq 0.5$ hold, the proposal $(\bar{E}, \bar{t})$ is a dominant education policy. Voters anticipate that this proposal will win the election at the second stage. In order to identify their preferred integration regime in this case, we compare the (expected) net income of an $\left(a_{i}, p_{j}\right)$-type with and without integration when the education policy is 'fixed' at $(\bar{E}, \bar{t})$. Using (2) and (3), we find

$$
\begin{aligned}
&\left.B_{i j}^{I}\right|_{(\bar{E}, \bar{t})}=\left(1-p_{j}\right) A(M) a_{i} \bar{E}+p_{j} \delta a_{i} \bar{E}-\bar{t} \gtreqless A(0) a_{i} \bar{E}-\bar{t}=\left.B_{i j}^{N I}\right|_{(\bar{E}, \bar{t})} \\
& \Longleftrightarrow p_{j} \gtreqless \frac{A(0)-A(M)}{\delta-A(M)}=p^{c} .
\end{aligned}
$$

\footnotetext{
${ }^{8}$ In Haupt and Uebelmesser (2007), we also find that in the presence of individuals who are heterogeneous in two dimensions labour-market integration potentially affects the educational choice. This is established in a setting with private investment in education and in the absence of political-economic considerations.
} 
That is, all citizens with a high migration probability $p_{j}$, i.e. $p_{j} \geq p^{c}$, vote for labour-market integration $(I)$ while those with a low probability $p_{j}$, i.e. $p_{j}<p^{c}$, favour non-integrated labour markets $(N I)$. This reflects the two opposing effects of integration. On the one hand, it provides the opportunity to take advantage of higher wages abroad. On the other hand, it depresses wages at home, as outmigration reduces the productivity of the domestic economy. The former positive effect on expected individual net income dominates the latter negative one for those individuals who are sufficiently mobile in terms of migration probability while the others suffer from integration.

The situation is very similar if $V^{I}<0.5$ and $V^{N I}<0.5$ hold. The proposal $(\underline{E}, 0)$ is then the dominant education policy. Comparing (expected) individual net incomes with and without integration when the education policy is 'fixed' at $(\underline{E}, 0)$ leads to

$$
\begin{gathered}
\left.B_{i j}^{I}\right|_{(\underline{E}, 0)}=\left(1-p_{j}\right) A(M) a_{i} \underline{E}+p_{j} \delta a_{i} \underline{E} \gtreqless A(0) a_{i} \underline{E}=\left.B_{i j}^{N I}\right|_{(\underline{E}, 0)} \\
\Longleftrightarrow p_{j} \gtreqless \frac{A(0)-A(M)}{\delta-A(M)}=p^{c},
\end{gathered}
$$

where we again made us of (2) and (3). As in the previous case, the mobile citizens favour integrated labour markets while the immobile ones prefer non-integrated markets. The probability threshold that divides the two groups is the same as before, and so are the reasons for the preferred policies.

We conclude that dominant education policies give rise to dominant integration policies. The question of whether proposal $(\bar{E}, \bar{t})$ or $(\underline{E}, 0)$ wins at the second stage does not influence the vote at the first stage, as long as the education policy is independent of the integration regime. Under these circumstances, the voters' preferred integration regimes depend only on their degree of mobility.

\subsection{INTEGRATION-DRIVEN EDUCATION POLICIES - FIRST CASE}

While the outcome of the vote on integration is straightforward with dominant education policies, it is less clear with integration-driven ones. Let us first consider the case in which $V^{I} \geq$ $0.5>V^{N I}$ holds. That is, the policy $(\bar{E}, \bar{t})$ will be the political outcome with integrated labour markets, and the policy $(\underline{E}, 0)$ with non-integrated ones. To identify the voters' preferences on integration, we now have to compare the (expected) individual net incomes that result from 
integrated labour markets $(I)$ and the induced education policy $(\bar{E}, \bar{t})$ with those that result from non-integrated labour markets $(N I)$ and the subsequent education policy $(\underline{E}, 0)$. From (2) and (3), it follows that

$$
\begin{gathered}
\left.B_{i j}^{I}\right|_{(\bar{E}, \bar{t})}=\left(1-p_{j}\right) A(M) a_{i} \bar{E}+p_{j} \delta a_{i} \bar{E}-\bar{t} \gtreqless A(0) a_{i} \underline{E}=\left.B_{i j}^{N I}\right|_{(\underline{E}, 0)} \\
\Longleftrightarrow a_{i} \gtreqless \frac{\bar{t}}{\left[A(M)+p_{j}(\delta-A(M))\right] \bar{E}-A(0) \underline{E}}=: a^{f i d}\left(p_{j}\right) .
\end{gathered}
$$

In this first case, the $a^{f i d}\left(p_{j}\right)$-borderline slopes downward and intersects the vertical $p^{c}$-line at $\left(p^{c}, a^{N I}\right)$, as can be easily checked. This is illustrated in Figure 2. The individuals to the right of the new borderline support labour-market integration while those to the left oppose it. Most importantly, the voters' preferred integration regimes now hinge not only on their mobility but also on their ability.

Figure 2: Voting on integration with integration-driven education policy (first case)

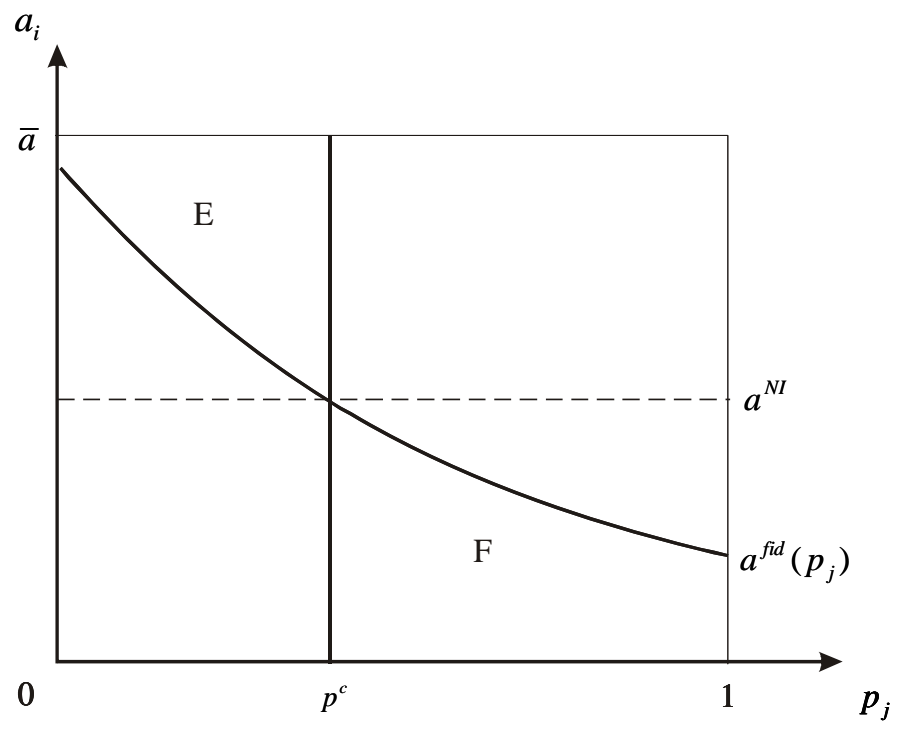

To understand the differences between this case and the previous one, we focus on the 'floating' voters of area-E and area-F type. The area-E type voters would oppose integration in the case of a dominant education policy for the reasons explored above. Their migration probability, however, is still rather close to the critical value $p^{c}$ so that their expected loss from integration is not too large. Moreover, their ability is rather high so that they can substantially gain from a high education quality $\bar{E}$. But the policy $(\bar{E}, \bar{t})$ will receive a majority in the 
succeeding election only if labour markets are integrated. The area-E types thus vote for integration $(I)$ in order to push their preferred education policy.

It is the opposite for area-F types. These voters would support integration in the case of a dominant education policy. Their expected benefits from integration, however, are not very large, since their migration probability exceeds the critical value $p^{c}$ only to a small extent. They would, moreover, face substantial losses if the education policy $(\bar{E}, \bar{t})$ were implemented, given their rather low ability. Consequently, the area-F types vote for non-integrated markets $(N I)$, as their preferred education policy $(\underline{E}, 0)$ only wins in a closed economy.

We have thus shown how the presence of these strategic effects distinguishes the case of integration-driven education policies from the case of dominant ones. If the education policy hinges on the integration regime, citizens have incentives to vote strategically on integration to promote their preferred education policy in the succeeding election. Then the impact of the integration regime on the succeeding education policy feeds back on the integration decision itself. In this sense, there is both a forward and a backward linkage between the two choices. This two-way relationship implies that the decision on integration depends not only on the citizens' mobility but also on their ability. By contrast, in the case of dominant education policies the vote on integration only hinges on individual mobility.

The fact that the proposal $(\bar{E}, \bar{t})$ would win in an open economy does not imply that labourmarket integration receives the majority of votes, and vice versa. To see this, we compare the threshold values $a^{f i d}\left(p_{j}\right)$ as defined in (9) and $a^{I}\left(p_{j}\right)$ as defined in (5)

$$
a^{f i d}\left(p_{j}\right) \gtreqless a^{I}\left(p_{j}\right) \Longleftrightarrow p_{j} \lesseqgtr \frac{A(0)-A(M)}{\delta-A(M)}=p^{c} .
$$

That is, the $a^{f i d}$-line is above the $a^{I}$-line up to the critical level $p^{c}$ and below it thereafter, as illustrated in Figure 3. Hence, neither does the set of supporters of policy $(\bar{E}, \bar{t})$ in an open economy completely contain the set of supporters of integrated labour markets, nor vice versa.

The area-G types always vote for the proposal $(\bar{E}, \bar{t})$ at the second stage, independent of the integration regime in place. This can be seen as these types are above both the bold $a^{I}$-line and the dotted $a^{N I}$-line. These citizens, nevertheless, vote against labour-market integration at the first stage, although they anticipate that their preferred education policy will be defeated at the polls in a closed economy. The reason is that given their rather low mobility level, they 
suffer more from integration than they could benefit from policy $(\bar{E}, \bar{t})$. In this sense, they prefer non-integrated markets and proposal $(\underline{E}, 0)$ to integrated markets and policy $(\bar{E}, \bar{t})$.

Unlike them, area-H types always vote for policy $(\underline{E}, 0)$ at the second stage, independent of the integration regime. This is indicated in Figure 3 where these types are below both the bold $a^{I}$-line and the dotted $a^{N I}$-line. Yet these citizens vote for labour-market integration at the first stage, although they know that their preferred education policy will lose in an open economy. But given their rather high mobility level, their expected benefits from integration simply outweigh their expected loss of net income caused by policy $(\bar{E}, \bar{t})$. In this sense, they prefer integrated markets and proposal $(\bar{E}, \bar{t})$ to non-integrated markets and policy $(\underline{E}, 0)$.

Figure 3: Integration regime and integration-driven education policy (first case)

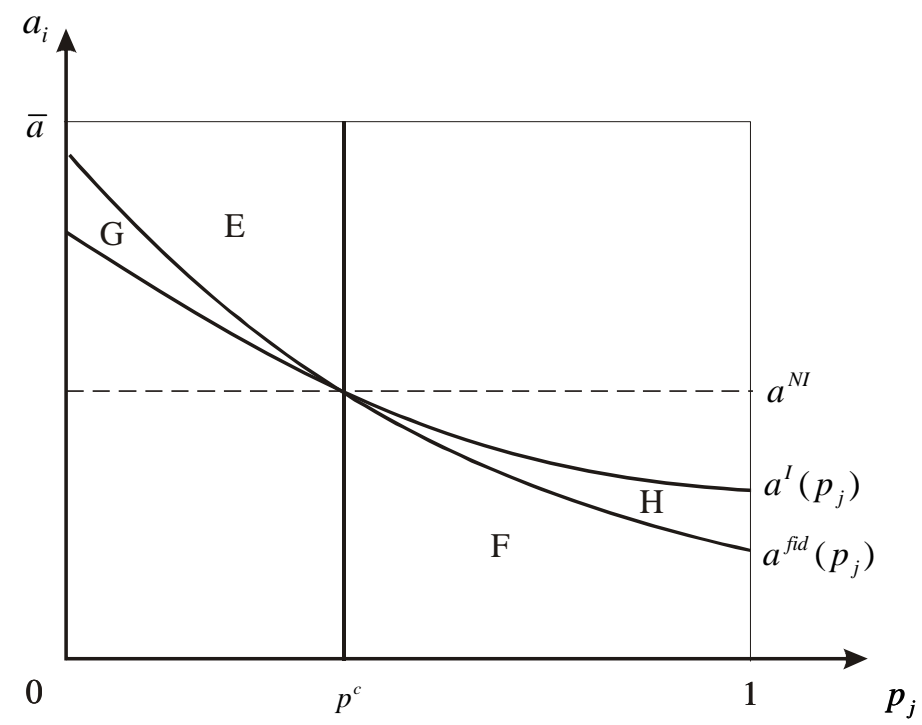

\subsection{INTEGRATION-DRIVEN EDUCATION POLICIES - SECOND CASE}

Finally, let us consider the case in which $V^{N I} \geq 0.5>V^{I}$ holds. Since the analysis of this case is analogous to the previous one, we can make it brief. Now, labour-market integration $(I)$ implies that education policy $(\underline{E}, 0)$ wins in the succeeding election while non-integrated markets $(N I)$ mean that policy $(\bar{E}, \bar{t})$ receives a majority. Comparing the resultant (expected) 
individual net incomes for this second case yields

$$
\begin{aligned}
\left.B_{i j}^{I}\right|_{(\underline{E}, 0)} & =\left(1-p_{j}\right) A(M) a_{i} \underline{E}+p_{j} \delta a_{i} \underline{E} \gtreqless A(0) a_{i} \bar{E}-\bar{t}=\left.B_{i j}^{N I}\right|_{(\bar{E}, \bar{t})} \\
& \Longleftrightarrow \quad a_{i} \lesseqgtr \frac{\bar{t}}{A(0) \bar{E}-\left[p_{j}(\delta-A(M))+A(M)\right] \underline{E}}=: a^{s i d}\left(p_{j}\right) .
\end{aligned}
$$

where we used again $(2)$ and (3). The $a^{\text {sid }}\left(p_{j}\right)$-borderline slopes upward and intersects the vertical $p^{c}$-line at $\left(p^{c}, a^{N I}\right)$, as illustrated in Figure 4. Now the individuals to the right of this borderline vote for labour-market integration while those to the left oppose it.

Figure 4: Voting on integration with integration-driven education policy (second case)

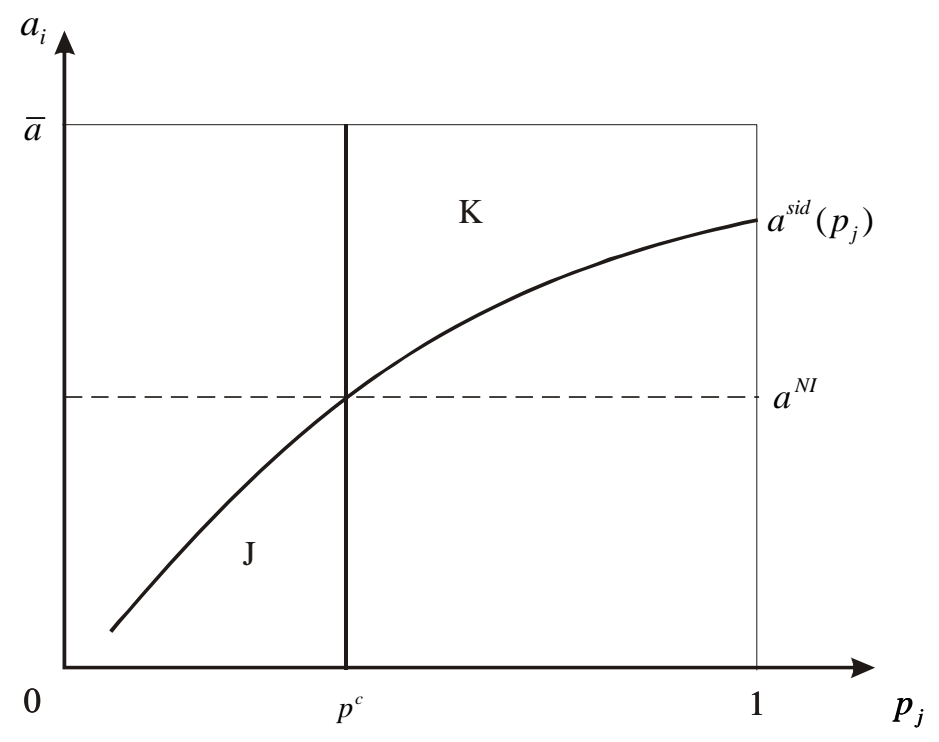

This voting behaviour is again compared with that in the case of a dominant education policy. As before, we focus on the 'floating' voters. Area-J types, who would oppose integration in the case of a dominant education policy, now support integration. By strategically voting for labour-market integration $(I)$, they push their preferred education policy $(\underline{E}, 0)$. In contrast to them, area-K types, who would favour integration in the case of a dominant education policy, now float into the anti-integration camp. They strategically vote for non-integrated labour markets $(N I)$ to ensure that their preferred education policy $(\bar{E}, \bar{t})$ wins the election. 


\section{TWO-DIMENSIONAL VOTING AND HETEROGENEITY}

Political problems are typically multidimensional, as in the current setting with two policy variables. In many circumstances, however, a hierarchy of decisions emerges; that is, decisions occur in a 'natural' sequence. As has already been discussed above, this is the case, for instance, when we consider short-run political choices within long-run institutional arrangements. Then, the decisions on the institutional framework are typically considered to take place prior to the decisions on policies within this framework; and the political decisions can be expected to be more easily changed than the institutional ones. Based on this reasoning, we have analysed sequential voting to determine the institutional and political equilibrium. We have thus partitioned the two-dimensional voting process into two uni-dimensional voting stages.

This approach is obviously convenient from a 'technical' perspective. As it is well-known, simultaneous voting on multi-dimensional issues causes severe methodological problems, since a Condorcet winner does not necessarily exist. ${ }^{9}$ Even in our very simple model, pairwise voting on the four alternatives $\{I,(\bar{E}, \bar{t})\},\{N I,(\bar{E}, \bar{t})\},\{I,(\underline{E}, 0)\}$ and $\{N I,(\underline{E}, 0)\}$ can lead to voting cycles. By splitting up the public decisions into two elections, we avoid such problems and generate a structure-induced equilibrium (cf. Shapsle, 1979).

But even if we can boil down political processes in this way, it is still important to consider the different votes as joint decisions and not as isolated ones. Analysing the interplay between the two elections does indeed provide additional insights, as the following example highlights.

Assume that for a given education policy, there is a slim majority for non-integrated labour markets $(N I)$. That is, the citizens whose migration probability $p_{j}$ is below the threshold value $p^{c}$ form a majority. Assume, moreover, that for non-integrated markets, the education policy $(\underline{E}, 0)$ narrowly wins at the polls. That is, the individuals whose ability $a_{i}$ is below the threshold value $a^{N I}$ comprise a majority. At first glance, one might expect that the outcome $(N I)$ and $(\underline{E}, 0)$ also constitutes an equilibrium once the two elections are jointly considered. But, as our analysis shows, this needs not to be the case.

If, for instance, the number of area-C types sufficiently exceeds that of area-B types (see Figure 1), then there will be a majority for education policy $(\bar{E}, \bar{t})$ in an open economy, as

\footnotetext{
${ }^{9}$ See, for instance, Persson and Tabellini (2000) and Mueller (2003) for an extensive discussion.
} 
argued above. This affects the share of votes in favour of labour-market integration. Once the number of area-E types sufficiently exceeds the number of area-F types (see Figure 2), the majority shifts in favour of labour-market integration at the first stage, indeed leading to education policy $(\bar{E}, \bar{t})$ at the second stage. The overall outcome is then $(I)$ and $(\bar{E}, \bar{t})$, which turns the results based on analysing the two elections as isolated decisions on its head.

Moreover, for a given education policy, only individual mobility determines whether a citizen favours labour-market integration or not in our setting. Once we consider the interaction between the two elections, a voter's decision on integration also hinges on her ability. Similarly, the preferences over different education policies do not only depend on ability but also on mobility. So multi-dimensional heterogeneity is important for voting outcomes, and its impact is particularly decisive when we consider multi-dimensional decisions. We are thus able to evaluate how increasing the heterogeneity with respect to the number of policy instruments affects the identity of the decisive group and the political equilibrium when voters (potentially) differ in several dimensions.

\section{CONCLUDING REMARKS}

This paper illustrates how long-run institutional and short-run political decisions are intertwined. In our setting, the decision on labour-market integration affects the succeeding education policy. Perhaps more surprisingly, the prospect of voting on education policy also influences the preceding integration choice. Citizens have incentives to vote strategically for the institutional setting that raises the number of votes in favour of their preferred education policy. So there is both a forward and a backward linkage between the two decisions. This interplay means that it is important to consider the two choices jointly. As we have argued, the resultant equilibrium policy can substantially differ from the outcomes that isolated votes would suggest. Also, the two-dimensional heterogeneity plays an important role when we consider the interplay of the two choices.

Our setting can be seen as reflecting some important aspects of the accession of the eastern European countries to the European Union, which will ultimately lead to the full integration of the new members into the common EU labour market. As the institutional decision is concerned, one might think of an eastern European country's vote on joining the EU (labour 
market). This is certainly a long-run decision in the sense that it is very difficult to reverse. Within the selected institutional framework, the country chooses its education policy. As this decision can be reversed almost anytime, it is of a more short-run nature.

Of course, accession affects not only the labour market and education policy, but influences many more areas of the citizens' political, social and economic life. Labour-market integration, however, is a particularly important part of the accession process. Given the close link between labour-market integration and education policy, we focus here on two relevant and intertwined policies. But as we always have to restrict our analysis to selected areas, we are not able to explore all phenomenons surrounding integration. For instance, the accession process normally involves a substantial amount of transfers to a poor country's (non-migrating) citizens, which - in the light of our model - can be thought of as benefits necessary to compensate them for any losses related to the opening of their country. These transfers might also explain why no poor country has yet declined to join the European Union. Extending the setting such that the large, rich jurisdiction is more explicitly modelled would allow us to incorporate these transfers and the strategic interactions between the jurisdictions in our analysis.

As a further extension, the underlying dynamics could be modelled more explicitly by applying an overlapping-generations approach. In such a framework, the parental generation decides on labour-market integration and the quality of education that their children receive. The basic outcome of this more sophisticated approach, however, would be the same as long as the parents' voting behaviour is sufficiently driven by their interest in their children's wellbeing. We think this is the case for two reasons. First, parents act altruistically regarding their offspring. Second, integration mainly affects their children, be it positive or negative, and not the parental generation, because of the time gaps between the institutional decision, the ultimate implementation, and the individual adjustment to the new institutional environment. ${ }^{10}$ Consequently, the parental choices are based on their expectations about their children's ability $a_{i}$ (i.e. their children's ability to benefit from education) and mobility $p_{j}$ (i.e. their children's ability to benefit from integration). Their votes are thus in line with the logic of our static setting. In this sense, our very tractable model can be interpreted as a 'reduced' form of an

\footnotetext{
${ }^{10}$ For instance, although the first eastern European countries already joined the EU in 2004, their citizens still cannot freely move to all old Member States as a result of transitional restrictions. And even the limited opportunities they have are rather used by the young, flexible generation than by the old, settled citizens.
} 
overlapping-generations approach.

We could further consider repeated voting in consecutive periods. In this case, citizens will most of the time decide on education policy only, given the fact that integration is less easily and therefore less often reversed. In 'single-issue' periods, our analysis of the voting behaviour in the second stage still applies. The majority, however, might vary over time as the composition of the citizens changes in the course of emigration.

Finally, the relationship between institutional and political decisions can be analysed in many other contexts. Consider, for instance, the interplay between economic and political integration on the one hand and tax policy on the other hand. The decision on integration affects the future tax policy, due to increased or decreased international competition. Once voters anticipate this link, it shapes their preferences over the integration regime. Many people indeed oppose globalisation because of its apparent impact on domestic policies. These issues, however, are left for future research. Also, a normative analysis that complements the current positive one can be the subject of future papers. 


\section{References}

[1] Alesina, Alberto, and Enrico Spolaore (1997): "On the Number and Size of Nations", The Quarterly Journal of Economics 112, 1027-1056.

[2] Alesina, Alberto, and Enrico Spolaore (2003): "The Size of Nations", Cambridge (Ma): MIT Press.

[3] Andersson, Frederik, and Kai A. Konrad(2003): "Human Capital Investment and Globalization in Extortionary States", Journal of Public Economics 87, 1539-1555.

[4] Barro, Robert J., and Xavier Sala-i-Martin (2003): Economic Growth, Second Edition, Cambridge (Ma.): MIT Press.

[5] Beine, Michel, Frédéric Docquier, and Hillel Rapoport (2008): "Brain Drain and Human Capital Formation in Developing Countries: Winners and Losers", The Economic Journal 118, 631-652.

[6] Boerner, Kira, and Silke Uebelmesser (2007): "Migration and the Welfare State: The Economic Power of the Non-Voter?", International Tax and Public Finance 14, 93-111.

[7] Bolton, Patrick, and Gérard Roland (1997): "The Breakup of Nations: A Political Economy Analysis", The Quarterly Journal of Economics 112, 1057-1080.

[8] De Fraja, Gianni (2001): "Education Policies: Equity, Efficiency and Voting Equilibrium", Economic Journal 111, C104-C119.

[9] Epple, Dennis, and Richard E. Romano (1996): "Ends against the Middle: Determining Public Service Provision When Rhere are Private Alternatives", Journal of Public Economics 62, 297-325.

[10] Fernandez, Raquel, and Richard Rogerson (1995): "On the Political Economy of Education Subsidies", Review of Economic Studies 62, 249-262.

[11] Glomm, Gerhard, and B. Ravikumar (1992): "Public versus Private Investment in Human Capital: Endogenous Growth and Income Inequality", Journal of Political Economy 100, 818-834. 
[12] Gradstein, Mark, and Moshe Justman (1997): "Democratic Choice of an Education System: Implications for Growth and Income Distribution", Journal of Economic Growth 2, 169-183.

[13] Haupt, Alexander (2005): "The Evolution of Public Spending on Higher Education Policy in a Democracy", CESifo Working Paper 1631, Munich.

[14] Haupt, Alexander, and Eckhard Janeba (2008): "Education, Redistribution, and the Threat of Brain Drain", International Tax and Public Finance, forthcoming.

[15] Haupt, Alexander, and Silke Uebelmesser (2007): "The Relation Between Mobility, Human Capital Formation, and Agglomeration", mimeo.

[16] Mueller, Dennis C. (2003): Public Choice III, Cambridge: Cambridge University Press.

[17] Persson, Torsten, and Guido Tabellini (2000): Political Economics - Explaining Economic Policy, Cambridge (Ma): MIT Press.

[18] Poutvaara, Panu (2008): "Public and Private Education in an Integrated Europe: Studying to Migrate and Teaching to Stay?", Scandinavian Journal of Economics 110, 591-608.

[19] Poutvaara, Panu (2006): "On the Political Economy of Social Security and Public Education", Journal of Population Economics 19, 345-365.

[20] Rangel, Antonio (2003): "Forward and Backward Intergenerational Goods: Why is Social Security Good for the Environment?", American Economic Review 93, 813-834.

[21] Shapsle, Kenneth A. (1979): "Institutional Arrangements and Equilibrium in MultiDimensional Voting Models", American Journal of Political Science 23, 27-59.

[22] Soares, Jorge (2003): "Self-Interest and Public Funding of Education", Journal of Public Economics 87, 703-727.

[23] Stark, Oded, Christian Helmenstein, and Alexia Prskawetz (1998): "Human Capital Depletion, Human Capital Formation, and Migration: A Blessing or a "Curse"?", Economics Letters 60, 363-367. 
[24] Stark, Oded, and Yong Wang (2002): "Inducing Human Capital Formation: Migration as a Substitute for Subsidies", Journal of Public Economics 86, 29-46.

[25] Stiglitz, Joseph E. (1974): "The Demand for Education in Public and Private School Systems", Journal of Public Economics 3, 349-385.

[26] Thum, Claudio, and Silke Uebelmesser (2003): "Mobility and the Role of Education as a Commitment Device", International Tax and Public Finance 10, 549-564.

[27] Vidal, Jean-Pierre (1998): "The Effect of Emigration on Human Capital Formation", Journal of Population Economics 11, 589-600.

[28] Wildasin, David (2000): "Labor Market Integration, Investment in Risky Human Capital, and Fiscal Competition", American Economic Review 90, 73-95. 


\section{CESifo Working Paper Series}

for full list see www.cesifo-group.org/wp

(address: Poschingerstr. 5, 81679 Munich, Germany, office@cesifo.de)

2525 Richard Arnott and Eren Inci, The Stability of Downtown Parking and Traffic Congestion, January 2009

2526 John Whalley, Jun Yu and Shunming Zhang, Trade Retaliation in a Monetary-Trade Model, January 2009

2527 Mathias Hoffmann and Thomas Nitschka, Securitization of Mortgage Debt, Asset Prices and International Risk Sharing, January 2009

2528 Steven Brakman and Harry Garretsen, Trade and Geography: Paul Krugman and the 2008 Nobel Prize in Economics, January 2009

2529 Bas Jacobs, Dirk Schindler and Hongyan Yang, Optimal Taxation of Risky Human Capital, January 2009

2530 Annette Alstadsæter and Erik Fjærli, Neutral Taxation of Shareholder Income? Corporate Responses to an Announced Dividend Tax, January 2009

2531 Bruno S. Frey and Susanne Neckermann, Academics Appreciate Awards - A New Aspect of Incentives in Research, January 2009

2532 Nannette Lindenberg and Frank Westermann, Common Trends and Common Cycles among Interest Rates of the G7-Countries, January 2009

2533 Erkki Koskela and Jan König, The Role of Profit Sharing in a Dual Labour Market with Flexible Outsourcing, January 2009

2534 Tomasz Michalak, Jacob Engwerda and Joseph Plasmans, Strategic Interactions between Fiscal and Monetary Authorities in a Multi-Country New-Keynesian Model of a Monetary Union, January 2009

2535 Michael Overesch and Johannes Rincke, What Drives Corporate Tax Rates Down? A Reassessment of Globalization, Tax Competition, and Dynamic Adjustment to Shocks, February 2009

2536 Xenia Matschke and Anja Schöttner, Antidumping as Strategic Trade Policy Under Asymmetric Information, February 2009

2537 John Whalley, Weimin Zhou and Xiaopeng An, Chinese Experience with Global 3G Standard-Setting, February 2009

2538 Claus Thustrup Kreiner and Nicolaj Verdelin, Optimal Provision of Public Goods: A Synthesis, February 2009 
2539 Jerome L. Stein, Application of Stochastic Optimal Control to Financial Market Debt Crises, February 2009

2540 Lars P. Feld and Jost H. Heckemeyer, FDI and Taxation: A Meta-Study, February 2009

2541 Philipp C. Bauer and Regina T. Riphahn, Age at School Entry and Intergenerational Educational Mobility, February 2009

2542 Thomas Eichner and Rüdiger Pethig, Carbon Leakage, the Green Paradox and Perfect Future Markets, February 2009

2543 M. Hashem Pesaran, Andreas Pick and Allan Timmermann, Variable Selection and Inference for Multi-period Forecasting Problems, February 2009

2544 Mathias Hoffmann and Iryna Shcherbakova, Consumption Risk Sharing over the Business Cycle: the Role of Small Firms' Access to Credit Markets, February 2009

2545 John Beirne, Guglielmo Maria Caporale, Marianne Schulze-Ghattas and Nicola Spagnolo, Volatility Spillovers and Contagion from Mature to Emerging Stock Markets, February 2009

2546 Ali Bayar and Bram Smeets, Economic and Political Determinants of Budget Deficits in the European Union: A Dynamic Random Coefficient Approach, February 2009

2547 Jan K. Brueckner and Anming Zhang, Airline Emission Charges: Effects on Airfares, Service Quality, and Aircraft Design, February 2009

2548 Dolores Messer and Stefan C. Wolter, Money Matters - Evidence from a Large-Scale Randomized Field Experiment with Vouchers for Adult Training, February 2009

2549 Johannes Rincke and Christian Traxler, Deterrence through Word of Mouth, February 2009

2550 Gabriella Legrenzi, Asymmetric and Non-Linear Adjustments in Local Fiscal Policy, February 2009

2551 Bruno S. Frey, David A. Savage and Benno Torgler, Surviving the Titanic Disaster: Economic, Natural and Social Determinants, February 2009

2552 Per Engström, Patrik Hesselius and Bertil Holmlund, Vacancy Referrals, Job Search, and the Duration of Unemployment: A Randomized Experiment, February 2009

2553 Giorgio Bellettini, Carlotta Berti Ceroni and Giovanni Prarolo, Political Persistence, Connections and Economic Growth, February 2009

2554 Steinar Holden and Fredrik Wulfsberg, Wage Rigidity, Institutions, and Inflation, February 2009

2555 Alexander Haupt and Tim Krieger, The Role of Mobility in Tax and Subsidy Competition, February 2009 
2556 Harald Badinger and Peter Egger, Estimation of Higher-Order Spatial Autoregressive Panel Data Error Component Models, February 2009

2557 Christian Keuschnigg, Corporate Taxation and the Welfare State, February 2009

2558 Marcel Gérard, Hubert Jayet and Sonia Paty, Tax Interactions among Belgian Municipalities: Does Language Matter?, February 2009

2559 António Afonso and Christophe Rault, Budgetary and External Imbalances Relationship: A Panel Data Diagnostic, February 2009

2560 Stefan Krasa and Mattias Polborn, Political Competition between Differentiated Candidates, February 2009

2561 Carsten Hefeker, Taxation, Corruption and the Exchange Rate Regime, February 2009

2562 Jiahua Che and Gerald Willmann, The Economics of a Multilateral Investment Agreement, February 2009

2563 Scott Alan Carson, Demographic, Residential, and Socioeconomic Effects on the Distribution of $19^{\text {th }}$ Century US White Statures, February 2009

2564 Philipp Harms, Oliver Lorz and Dieter Urban, Offshoring along the Production Chain, February 2009

2565 Patricia Apps, Ngo Van Long and Ray Rees, Optimal Piecewise Linear Income Taxation, February 2009

2566 John Whalley and Shunming Zhang, On the Arbitrariness of Consumption, February 2009

2567 Marie-Louise Leroux, Endogenous Differential Mortality, Non-Contractible Effort and Non Linear Taxation, March 2009

2568 Joanna Bęza-Bojanowska and Ronald MacDonald, The Behavioural Zloty/Euro Equilibrium Exchange Rate, March 2009

2569 Bart Cockx and Matteo Picchio, Are Short-Lived Jobs Stepping Stones to Long-Lasting Jobs?, March 2009

2570 David Card, Jochen Kluve and Andrea Weber, Active Labor Market Policy Evaluations: A Meta-analysis, March 2009

2571 Frederick van der Ploeg and Anthony J. Venables, Harnessing Windfall Revenues: Optimal Policies for Resource-Rich Developing Economies, March 2009

2572 Ondřej Schneider, Reforming Pensions in Europe: Economic Fundamentals and Political Factors, March 2009 
2573 Jo Thori Lind, Karl Ove Moene and Fredrik Willumsen, Opium for the Masses? Conflict-Induced Narcotics Production in Afghanistan, March 2009

2574 Silvia Marchesi, Laura Sabani and Axel Dreher, Agency and Communication in IMF Conditional Lending: Theory and Empirical Evidence, March 2009

2575 Carlo Altavilla and Matteo Ciccarelli, The Effects of Monetary Policy on Unemployment Dynamics under Model Uncertainty - Evidence from the US and the Euro Area, March 2009

2576 Falko Fecht, Kjell G. Nyborg and Jörg Rocholl, The Price of Liquidity: Bank Characteristics and Market Conditions, March 2009

2577 Giorgio Bellettini and Filippo Taddei, Real Estate Prices and the Importance of Bequest Taxation, March 2009

2578 Annette Bergemann and Regina T. Riphahn, Female Labor Supply and Parental Leave Benefits - The Causal Effect of Paying Higher Transfers for a Shorter Period of Time, March 2009

2579 Thomas Eichner and Rüdiger Pethig, EU-Type Carbon Emissions Trade and the Distributional Impact of Overlapping Emissions Taxes, March 2009

2580 Antonios Antypas, Guglielmo Maria Caporale, Nikolaos Kourogenis and Nikitas Pittis, Selectivity, Market Timing and the Morningstar Star-Rating System, March 2009

2581 António Afonso and Christophe Rault, Bootstrap Panel Granger-Causality between Government Budget and External Deficits for the EU, March 2009

2582 Bernd Süssmuth, Malte Heyne and Wolfgang Maennig, Induced Civic Pride and Integration, March 2009

2583 Martin Peitz and Markus Reisinger, Indirect Taxation in Vertical Oligopoly, March 2009

2584 Petra M. Geraats, Trends in Monetary Policy Transparency, March 2009

2585 Johannes Abeler, Armin Falk, Lorenz Götte and David Huffman, Reference Points and Effort Provision, March 2009

2586 Wolfram F. Richter, Taxing Education in Ramsey’s Tradition, March 2009

2587 Yin-Wong Cheung, Menzie D. Chinn and Eiji Fujii, China's Current Account and Exchange Rate, March 2009

2588 Alexander Haupt and Silke Uebelmesser, Voting on Labour-Market Integration and Education Policy when Citizens Differ in Mobility and Ability, March 2009 